\title{
Features of personnel policy and the system of state civil service in the Republic of Uzbekistan
}

\section{Otabek MAKHKAMOV ${ }^{1}$}

Academy of Public Administration

\begin{tabular}{l} 
ARTICLE INFO \\
\hline Article history: \\
Received September 2020 \\
Received in revised form \\
15 September 2020 \\
Accepted 15 October 2020 \\
Available online \\
30 October 2020
\end{tabular}

Keywords:

Public service

state civil servant

Managerial personnel

Recruitment

Competence

Assessment

Methods.

\begin{abstract}
The article analyzes the legal foundations of personnel policy and the state civil service in the Republic of Uzbekistan, as well as the features of training, selection and assessment of the competencies of state civil servants. Based on the analysis of modern challenges, proposals are given for further improving the system of state civil service of the Republic of Uzbekistan

2181-1415/@ 2020 in Science LLC.

This is an open access article under the Attribution 4.0 International (CC BY 4.0) license (https://creativecommons.org/licenses/by/4.0/deed.ru)
\end{abstract}

\section{Ўзбекистон Республикасида кадрлар сиёсати ва давлат фуқаролик хизматининг ўзига хос хусусиятлари}

\author{
Калит сўзлар: \\ Давлат фуқаролик \\ хизмати \\ Давлат фуқаролик \\ хизматчилари \\ Рахбар кадрлар \\ Компетенция \\ Кадрларни танлаш \\ Бахолаш \\ Усуллар
}

\section{АННОТАЦИЯ}

Мақолада Ўзбекистон Республикасида кадрлар сиёсати ва давлат фуқаролик хизматининг норматив-хуқуқий асослари, шунингдек, давлат фуқаролик хизматчиларини ўқитиш, танлаш ва компетенцияларини бахолаш тахлил қилинган. Замонавий муаммолар тахлили асосида Ўзбекистон Республикасида давлат фуқаролик хизматини такомиллаштириш юзасидан таклифлар ишлаб чиқилган. 


\section{Особенности кадровой политики государственной гражданской службы \\ И системы Узбекистан \\ в Республике}

Ключевые слова:

Государственная служба

Государственный

гражданский служащий

Рукаводящие кадры

Подбор кадров

Компетенция

Оценка

Методы

\begin{abstract}
АННОТАЦИЯ
В статье проанализированы правовые основы кадровой политики и государственной гражданской службы в Республике Узбекистан, а также особенности обучения, подбора и оценки компетенций государственных гражданских служащих. На основании анализа современных вызовов даны предложения по дальнейшему совершенствованию системы государственной гражданской службы республики Узбекистан.
\end{abstract}

\section{INTRODUCTION}

The first twenty years of Uzbekistan's independent development have made it possible to take priority measures and create basic legislative acts regulating public relations in the state civil service. In recent years, large-scale changes have been under way to improve the efficiency of the public service in the country.

At the same time, a number of systemic problems and shortcomings persist, leading to insufficient provision the State bodies and organizations by qualified specialists, and in the inadequacy of the personnel qualifications to meet the tasks and modern needs, as well as poor quality of decision-making process. In particular, there is no directly applicable law that provides comprehensive legal regulation of the state civil service, including open, independent competitive selection procedures; as well as defining criteria for evaluation the performance and competence of state civil servants, requirements for improving their qualifications.

Dozens of laws and regulations have been adopted to address these problems. These include the Constitution of the Republic of Uzbekistan, the National Program on Personnel Training, Presidential decrees and decisions and the Cabinet of Ministers Resolutions. In particular, such legislation includes:

Decrees of the President of the Republic of Uzbekistan "On measures to radically improve personnel policy and the system of state civil service in the Republic of Uzbekistan" (October 3, 2019 No.PD-5843) and "On measures to further enhance the system of training, retraining and advanced training of management personnel at the Academy of Public Administration under the President of the Republic of Uzbekistan"(August 8, 2017 No.PD5139);

Resolution of the President of the Republic of Uzbekistan "On measures for the organization of activities of the Agency of development of public service under the President of the Republic of Uzbekistan" (October 3, 2019 No. PP-4472), "About organization of regional branches of the Academy of Public Administration under the President of the Republic of Uzbekistan" (August 6, 2018 No. PP-3901) and "On additional measures to improve the system of training, retraining and advanced training of management personnel at the Academy of Public Administration under the President of the Republic of Uzbekistan" (June 27, 2019 No. PP-4365); 
Resolutions of the Cabinet of Ministers of the Republic of Uzbekistan "On approval of regulatory legal acts concerning the training, retraining and advanced training of management personnel" (September 19, 2017 No. 745) and "On measures to organize the activities of regional branches of the Academy of Public Administration under the President of the Republic of Uzbekistan " (September 28, 2018 No. 772).

The above-mentioned legal acts embody the fundamental concepts of the state civil service. These include:

State Civil Service;

State Civil Servant;

Managerial Personnel;

Training, retraining and advanced training of managerial personnel;

competencies of managerial personnel and civil servants;

principle of meritocracy;

«Career model»;

competitive selection;

HR units, etc.

According to the Decree of the President of the Republic of Uzbekistan "On measures to radically improve personnel policy and the system of state civil service in the Republic of Uzbekistan" (October 3, 2019 No.PD-5843) "a state civil servant is a citizen of the Republic of Uzbekistan who performs activities in the posts, which have been recorded in the State Register of Posts"2.

It should be noted that the State Register of Posts has not yet been approved, but it would be advisable to include the State bodies at four levels: national, republican, regional and district levels.

The national level will include the Oliy Majlis, the Presidential Administration and the Cabinet of Ministers.

To the republican level the ministries, state committees, agencies and other organizations.

To the regional level khokimiyats (mayor's office) of the regions, as well as of the directorates and regional branches of republican level bodies.

To the district level khokimiyats of districts and cities, as well as departments of government bodies.

Citizens of foreign States and persons who have been declared stateless persons may hold state civil service posts in accordance with the procedure established by individual decisions of the President of the Republic of Uzbekistan.

Military service in the Armed Forces of the Republic of Uzbekistan and service in law enforcement agencies is a State special service and is regulated by individual legislative acts.

On the basis of the foregoing, it can be concluded that the public service of the Republic of Uzbekistan can be divided into two types: civil and special services.

We would like to note that the above-mentioned Decree also approved the «Program of Priority Measures for the Radical Improvement of the Personnel Policy and the System of the State Civil Service in the Republic of Uzbekistan», which includes 27 paragraphs and the adoption of 2 Cabinet of Ministers Resolutions and more than 10 other documents.

Besides the term «state civil servant» in the legislation there is phrase «managerial personnel». Since there is currently no single definition of the term, it can be seen from the

\footnotetext{
${ }^{2}$ https://www.lex.uz/docs/4549993
} 
practice of admission to the Master's degree of the Academy of Public Administration. Thus, according to the Presidential Decree "On measures to further enhance the system of training, retraining and advanced training of management personnel at the Academy of Public Administration under the President of the Republic of Uzbekistan"(August 8, 2017 No.PD5139) the admission process to the Master's Degree of the Academy is carried out on the basis of a competition exclusively from among the persons recommended by the State authorities, government and economic bodies, as well as public organizations and economic entities of the Republic of Uzbekistan, under the age of 40, having a basic higher education and at least 2 years of managerial experience. ${ }^{3}$ In the category of managerial experience, it is generally customary to include work at the leadership level, on which the success of the government, organization, institutions, enterprises and local government bodies depends decisively. For example, staff working in managerial positions can be cited as leadership of organizations and their deputies, heads of department, divisions, offices and units. In some cases, chief inspectors/specialists of national or regional level may be recognized as managerial personal because of their functional responsibilities for monitoring and coordinating the activities of lower-level organizations.

Based on the foregoing, it can be defined that the concept of "state civil servant" is broader than the concept of "managerial personnel". This conclusion is still based on the fact that the so-called "class ranks" - "classification ranks" of state civil servants - are being developed. The matrix of which is taken into account and management personnel.

Speaking about the training system of managerial personnel, it would be noted that today it includes 3 types:

1. Training - one- or two-year Master's degree program in full-time and part-time forms. time form.

2. Retraining - four-month and ten-month medium-term courses in full-time and part-

3. Advanced training - the short-term courses lasting up to 1 month.

On the basis of the Decree of the President of the Republic of Uzbekistan "On measures to further enhance the system of training, retraining and advanced training of management personnel at the Academy of Public Administration under the President of the Republic of Uzbekistan"(August 8, 2017 No.PD-5139) introduced a new system of selection of listeners on the competency-base assessment approach. ${ }^{4}$

Thus, in 2017, five main competencies were adopted for the selection of listeners for training (Master degree) and retraining programs. These include:

1. Values

2. Managerial professionalism

3. Leadership

4. Systemic Thinking

5. Adaptability

Based on these competencies, the three stages listeners selections is established:

The first stage is the initial selection of candidates directly from state authorities, government and economic bodies, non-governmental non-profit organizations from among those in reserve for managerial positions.

\footnotetext{
${ }^{3}$ https://www.lex.uz/docs/3300782

${ }^{4}$ https://www.lex.uz/docs/3300782
} 
The second stage is the candidates' passing of Tests on knowledge of the history of Uzbekistan and determining the level of logical thinking conducted by the State Testing Center under the Cabinet of Ministers of the Republic of Uzbekistan.

The third stage is for candidates to be interviewed to assess their administrative skills, logical, systemic and analytical thinking, and to determine their leadership qualities.

Advanced training courses of managerial personnel is carried out on the orders bases from state authorities, government and economic bodies, non-governmental non-profit organizations and business entities on a contractual basis.

It should be noted that in 2018 regional branches of the Academy were opened in the cities of Gulistan, Karshi, Samarkand, Urgench and Fergana, which allowed the organization of advanced training, including in the regions of Uzbekistan.

Advanced training courses at the Academy and its regional branches are carried out on the basis of a decision of the Cabinet of Ministers, which determines the quotas of listeners (annually more than 4,000 public servants on the basis of a grant and more than 2,000 paidcontract basis).

New interactive training methods, trainings and webinars have been introduced in the process of organizing advanced training courses. The program includes modules on the formation of deep and practice-oriented knowledge in the field of local government and regional development, strategic planning skills, horizontal and vertical relations system, skills of quality performance of state and regional programs, regulations, as well as the formation of skills of planning activities, quality execution of plans ("road maps") and others. ${ }^{5}$

The aforementioned Presidential Decree No.PD-5843 dated on October 3, 2019 for the first time at the legislative level applied such international terms as "the principle of meritocracy" and "career model", the implementation of which will have a qualitative impact in improving the public civil service.

On the basis of these principles, a transparent system of recruitment and further promotion of personnel is created. In connection with this, the basic competences of state civil servants have been developed and a new selection procedure for the public service has been introduced. The Agency for the Development of Public Service, the Ministry of Employment and Labour Relations, Ministry of Finance and Ministry Agriculture were taken as an experiment.

Competitive selection will be carried out from among the candidates included by the National Personnel Reserve.

Based on the foregoing, it is proposed to select candidates on the basis of a competent approach, which will result in a kind of passport-skills and an annual development plan for a state civil servant under 8 main competencies:

1. Managerial professionalism

2. Leadership

3. Communication

4. Adaptability

5. Result orientation

6. Systemic Thinking

7. Social values

8. Openness to new experiences

The selection is proposed in four stages:

\footnotetext{
${ }^{5}$ https://www.lex.uz/docs/3924316
} 
The first stage - study of personal data (passport data, reference lens, working experience, skills in foreign languages and ICT, etc.).

The second stage - psychological diagnosis (psychological tests on values, decisionmaking, systemic thinking, emotional intelligence, etc.).

The third stage - knowledge testing (ICT, foreign languages, economics, law, history, spirituality, etc.).

The fourth stage - evaluation competencies by means of Assessment center (cases, interviews, brainstorming, presentation, etc.).

Implementation of this kind of selection, in our view, will allow elaborating an individual plan for the development of a civil servant at all stages, which includes the enhancing of specific knowledge and skills to effectively and efficiently fulfill their functional responsibilities.

With the selection and evaluation of the competencies of civil servants relevant, we believe that a more detailed discussion of some aspects of the personnel divisions / HR Units is relevant.

The President's decree of October 3, 2019 defines the main tasks of the personnel divisions / HR Units of state bodies and organizations:

Implementation of the most transparent and equitable procedure for the selection and placement of staff using modern information and communication technologies;

Improving the personnel / human resources management mechanism on the basis of modern management systems based on successful foreign experience;

Formulation and implementation of a personnel management policy aimed at achieving and maintaining the quantitative and qualitative characteristics of the staff to meet the objectives of State bodies and organizations;

To meet the needs of State bodies and organizations in accordance with their objectives and development strategy, as well as with the changing external and internal conditions of the labour market;

Creation of equal opportunities for career development, based on objective assessment of work performance, moral and willful qualities, abilities and skills of employees of State bodies and organizations;

Facilitating to increase the individual contribution of each employee to the achievement of the objectives of government bodies and organizations through the continuous development and maximum utilization of the potential of the staff;

Taking effective measures to develop a professional ethics, anti-corruption culture and zero-tolerance for corruption among civil servants;

Organization of regular professional development, including life-long learning (by specialized and highly qualified professionals), including training abroad 6 .

As for the latter task, the same resolution provides for the development of a five-year program for phased-out internships for a period of 3 to 6 months, at least 1000 of the most promising mid- and lower-level employees of the state and government agencies in the relevant bodies and organizations of developed foreign countries.

At the same time, the Presidential Decree No.PD-5843 dated on October 3, 2019 establishes a rule under which public bodies and organizations are obliged to ensure that public civil servants take annual full-time short-term advanced training courses (from 30 to 60 hours).

\footnotetext{
${ }^{6}$ https://www.lex.uz/docs/4552055
} 
The above brief analysis of legal and regulatory acts makes it possible to identify additional challenges and tasks that need to be addressed, in particular:

First, unfortunately, there is currently no single law on the civil service that would incorporate the basic principles and mechanisms for the implementation of personnel policy and the civil service. Taking into account that the first draft of the law is more than 20 years old and that the current version is under intense of public and expert discussion. In our view, taking into account the comments made, it would be advisable to approve the Interim Civil Service Regulations and having been tested by several State bodies for adopting the Act thereafter.

Secondly, the performance of human resources units must be critically reviewed. In our view, human resources units are currently not fully fulfilling their functional responsibilities. Most of their activities are related to technical and paper-based work. First and foremost, human resources units should be restructured and renamed into departments, offices and human resources development units. At the same time, it is mandatory to provide such staff units as the department (specialist) of labor relations, personnel planning and employment, selection and placement of personnel, work with the personnel reserve, career modeling and evaluation of activities, monitoring of the career growth of employees, evaluation of work, personnel development, training of employees and on the social and psychological climate of the organization. Meanwhile, it is necessary to approve the forms, minimum standards and criteria for the formation of personnel units/ HR Units, as well as the levels of staff in State bodies and organizations, on the basis of the level and staff of State bodies and organizations.

Third, the functional responsibilities of state civil servants do not correspond to contemporary realities and are in most cases merely declaratory. In particular, functional responsibilities should be anchored in practices that promote organizational development and produce concrete results, should not be of a general nature and have to be in no case be unduly expanded. Public civil servants should effectively represent their rights and obligations, the performance of which would determine their efficiency and effectiveness. In our view, therefore, it is necessary to review the functional responsibilities of all public civil servants and to develop new ones based on the mission, vision and priorities of each organization. These changes in the future will make it possible to develop the real competencies of civil servants, which will be used in the selection and placement of staff, as well as in further career development.

Fourthly, in view of the need to systematically study and improve the competencies of state civil servants, it is advisable to create a new unit in the form of an Assessament centre attached to the Agency for the Development of Public Service. Its main tasks will include the development of competences and their methodology of evaluation, the coordination of personnel units in the conduct of competency assessments, the introduction of new methods for the evaluation of civil servants, etc.

Fifthly, at present there is no training in the specialty «state management», «local management» and «human resources management» on undergraduate programs. In this connection, we believe that it would be appropriate to open new majors and specializations for the training of personnel under the above-mentioned names at the Academy. This change will make it possible to systematize management training, which will undoubtedly have a positive impact on the development of the civil service.

Sixth, the reform of postgraduate education is a logical extension of the educational process. In this regards it is considered expedient to pay special attention to creation of 
scientific direction or, generally speaking of the specialty «State Administration», to allocate quotas for training in doctoral studies, to create on the basis of the Academy of Scientific Council. In our view, the implementation of this idea will give new impetus to fundamental and applied research on the issues of public administration and personnel policy.

In conclusion, we would like to emphasize that in recent years wide-ranging reforms have been carried out in every area of national life. It is at this time when reforms are being implemented at an accelerated pace that there is an urgent need to develop the highly qualified skills of civil servants. In our view, the proposals we have put forward will give new impetus to the improvement of personnel policy in our country.

\section{References}

1. The Constitution of the Republic of Uzbekistan (https://www.lex.uz/docs/35869).

2. The National Programme on Personnel Training (https://www.lex.uz/docs/19769).

3. Decrees of the President of the Republic of Uzbekistan "On measures to radically improve personnel policy and the system of state civil service in the Republic of Uzbekistan" (October 3, 2019 No.PD-5843) (https://www.lex.uz/docs/4549993).

4. Decrees of the President of the Republic of Uzbekistan "On measures to further enhance the system of training, retraining and advanced training of management personnel at the Academy of Public Administration under the President of the Republic of Uzbekistan"(No. УП-5139, dated August 8, 2017) (https://www.lex.uz/docs/3300782).

5. Resolution of the President of the Republic of Uzbekistan "On measures for the organization of activities of the Agency of development of public service under the President of the Republic of Uzbekistan" (October 3, 2019 No. PP-4472) (https://www.lex.uz/docs/4552055).

6. Resolution of the President of the Republic of Uzbekistan "About organization of regional branches of the Academy of Public Administration under the President of the Republic of Uzbekistan" (August 6, 2018 No. PP-3901) (https://www.lex.uz/docs/3859712).

7. Resolution of the President of the Republic of Uzbekistan "On additional measures to improve the system of training, retraining and advanced training of management personnel at the Academy of Public Administration under the President of the Republic of Uzbekistan" (June 27, 2019 No. PP-4365); (https://www.lex.uz/docs/4389748).

8. Resolutions of the Cabinet of Ministers of the Republic of Uzbekistan "On approval of regulatory legal acts concerning the training, retraining and advanced training of management personnel" (September 19, 2017 No. 745) (https://www.lex.uz/docs/3358153).

Resolutions of the Cabinet of Ministers of the Republic of Uzbekistan "On measures to organize the activities of regional branches of the Academy of Public Administration under the President of the Republic of Uzbekistan " (September 28, 2018 No. 772) (https://www.lex.uz/docs/3924316 